\title{
OPTIMIZATION OF TIN RECOVERY FROM CONCENTRATES THROUGH A MODEL FOR PREDICTION OF SLAG COMPOSITION*
}

Daniel Mapa Clemente ${ }^{1}$ Carlos Antônio da Silva ${ }^{2}$ Itavahn Alves da Silva ${ }^{3}$

\begin{abstract}
Processing of tin slags in reduction furnaces was studied in order to optimize tin recovery and reduce recirculation rates of slags containing thorium and uranium oxides. A theoretical approach considering a mass balance of the process was developed and adjusted by experimental results in order to predict the final slag composition. A metallic phase (FeSnSi) was discovered trapped in the slag due to high apparent viscosity, raising the $\mathrm{FeO}$ and $\mathrm{SnO}_{2}$ contents of the slag sample. This FeSnSi alloy is rich in tin and its recovery would help to reduce the slags recirculation. High contents of $\mathrm{ZrO}_{2}$ were found in the slag, restricting it from reaching complete fluid phase. Through an analysis of the slag in the $\mathrm{CaO}-\mathrm{FeO}-\mathrm{SiO}_{2}$ and $\mathrm{ZrO}_{2}-\mathrm{CaO}-\mathrm{SiO}_{2}$ phase systems it can be concluded that final slags should be modeled aiming fluid phase at working conditions and additions should be planned in order to control $\mathrm{ZrO}_{2}$ levels.
\end{abstract}

Keywords: Slag model; Tin recovery; Tin slag; Process optimization.

1 MSc, Metallurgical Engineer, Process Development, Resind Indústria e Comércio Ltda, São João Del Rei, Minas Gerais, Brazil.

2 PhD, Professor, Departamento de Engenharia Metalúrgica e de Materiais, Escola de Minas, UFOP, Ouro Preto, Minas Gerais, Brazil.

3 DSc. Professor, Departamento de Engenharia Metalúrgica e de Materiais, Escola de Minas, UFOP, Ouro Preto, Minas Gerais, Brazil. 


\section{INTRODUCTION}

The discussion on the protection of workers and public from radiation has been intensified in many regions of the world in the past years and new regulations are being implemented as for example in the European Union [1] and Brazil [2]. These regulations reinforce the need for some sectors of the metallurgical and mining industry to focus on protection of individuals exposed to radiation. Included are industries working with minerals or slags containing radionuclides from the natural thorium and uranium series, such as the tin industry $[3,4]$. The production of tin is performed classically according to Figure 1. Through processing of concentrates containing this element, the outputs are crude tin, FeSn, filter dust and slag. As shown in Figure 1, there is reprocessing of by-products [5]. In this context, the optimization of metallurgical processes aiming higher recovery of tin can aid reducing the rate of recirculation of concentrates or slags containing thorium and uranium, thus contributing to reduce the operator's exposure to radiation.

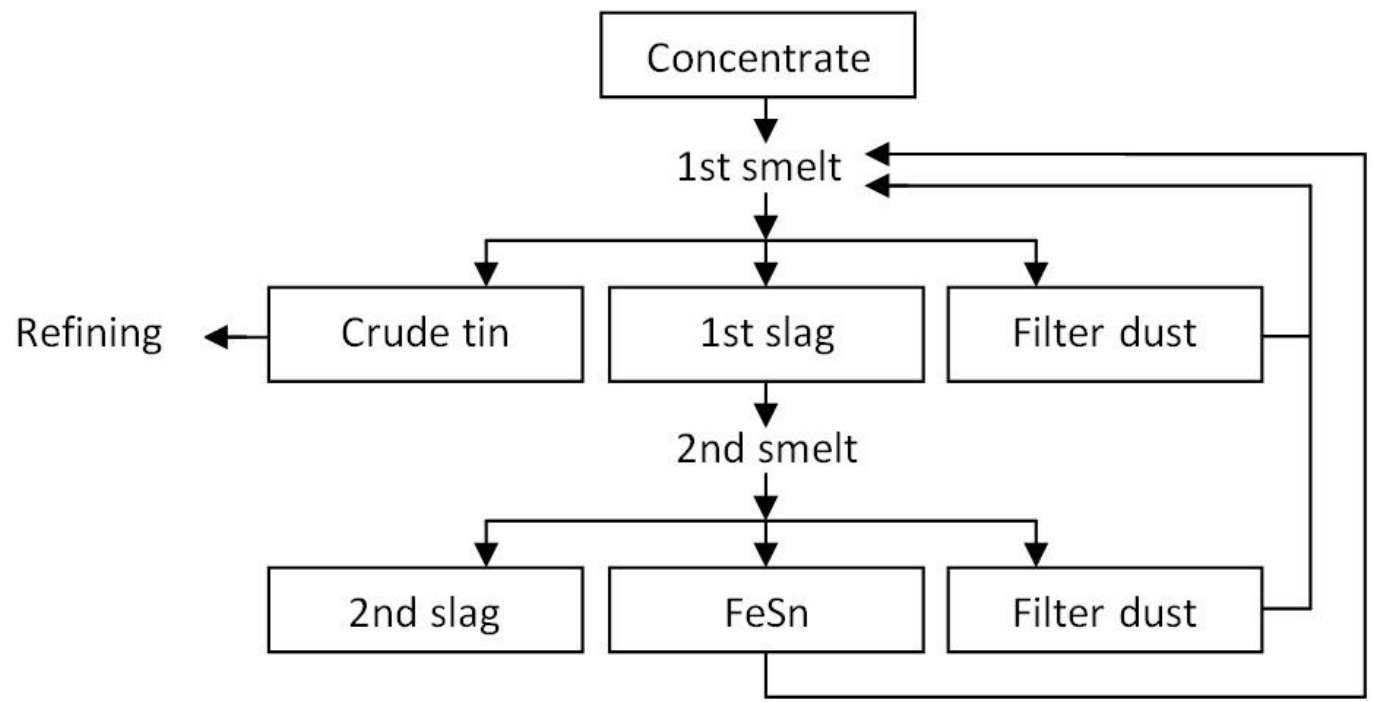

Figure 1. Production of tin by conventional process. Adapted from Wright [5].

An example of optimization tool is a model for slag prediction that, according to Pretorius and Marr [6], can be used in the metallurgical industry to reduce processing time, minimize refractory wear and improve predictability of operations. This model can be constructed based on a mass balance taking all factors that compose the final slag into account [6]. The fluidity of slag is considered by Wright [5] and Pretorius [7] as an important property for slags. Regarding tin slags its importance is related to the influence on the metal/slag separation and therefore on the recovery of tin [5].

Based on this information, a prediction model can also aid in the production of tin from concentrates, since the addition of fluxes can be better calculated and a lower melting temperature and higher fluidity of the slag can be targeted. In this context, a possible control parameter is the basicity $\left(\% \mathrm{CaO} / \% \mathrm{SiO}_{2}\right)$.

Tin slags can be described classically by the $\mathrm{CaO}-\mathrm{FeOx}-\mathrm{SiO}_{2}$ phase system. Other oxides that form the slag are: $\mathrm{P}_{2} \mathrm{O}_{5}, \mathrm{TiO}_{2}, \mathrm{Nb}_{2} \mathrm{O}_{5}, \mathrm{Ta}_{2} \mathrm{O}_{5}, \mathrm{ZrO}_{2}, \mathrm{ThO}_{2}$ and $\mathrm{SnO}_{2}$ [5]. It is therefore a highly complex slag. Considering that $\mathrm{ThO}_{2}$ resides in the slag phase after the end of the process, it is interesting to study the reprocessing optimization of these slags in order to avoid/reduce additional steps. 
The main objective of this work is therefore the development of a model capable of predicting the slag composition and optimizing the tin recovery.

\section{MATERIAL AND METHODS}

In the present work a tin concentrate originated from slags treated in a mineral processing circuit (jigs, spirals and shaking tables) was used as object of study. A clear difference between this concentrate and the final slags described by Wright [5] is the high $\mathrm{ZrO}_{2}$ content, possibly due to characteristics of Brazilian ores and reconcentration in the mineral processing circuit. In order to simplify the problem, thus allowing an initial study on the ideal composition of final slags, only the influence of $\mathrm{CaO}, \mathrm{FeO}, \mathrm{SiO}_{2}$ and $\mathrm{ZrO}_{2}$ on the melting temperature of final slags were analyzed. The $\mathrm{CaO}-\mathrm{FeO}_{x}-\mathrm{SiO}_{2}$ system was studied for comparison between concentrate and final slags from the present work and classical tin slags described by Wright [5].

For the model, the composition and mass of tin concentrate, fluxes and additives, outputs (FeSnSi, crude tin and final slag) as well as filter dust were considered. It was possible to build a model to predict the theoretical composition of the final slag. This prediction was compared with experimental results, whose tests were carried out in a pilot furnace of a metallurgical company. Based on the results, the model could be optimized.

Phase diagrams described by Verein Deutscher Eisenhüttenleute [8] and Kwon [9] were used to study the composition and melting temperature of the slag, considering the $\mathrm{CaO}-\mathrm{FeO}_{x}-\mathrm{SiO}_{2}$ and $\mathrm{ZrO}_{2}-\mathrm{CaO}-\mathrm{SiO}_{2}$ phase systems, respectively. A theoretical approach on the influence of $\mathrm{ZrO}_{2}$ on the viscosity of slag was also discussed. Verein Deutscher Eisenhüttenleute [8] describes viscosity models, including the model of Ribound et al and Urbain et al. In the estimation of viscosities, $\mathrm{ZrO}_{2}$ is treated as acid oxide in the first and as a basic oxide in the last model, indicating that it has a amphoteric behavior. As the Ribound et al model was developed for mould fluxes, an analysis of the slags of the acidic slags of the present work under the scope of the model proposed by Urbain et al was used.

In the present study, 13 tests were performed concerning processing of tin concentrate and the last test was done in order to verify a second sampling method. For the experiments, a three-phase electric arc furnace with 500 kVA and alternate current was used. The furnace crucible was lined with carbon paste as well as the slag ladle, in order to avoid influence of possible refractory wear on the slag composition. Tapping temperatures were monitored by a digital infrared thermometer from the company Instrutherm.

Raw materials, filter dust and final slags were sampled according to the standard D75/D75M [10], being final slags grinded for better homogenization $(<1 \mathrm{~mm})$. Subsequently, due to verification of a metal phase (FeSnSi alloy) in the ground final slag, another sampling method was performed in order to avoid collecting metallic fraction while sampling the slag. A steel rod was inserted into the slag stream during tapping and the solidified slag layer around the rod was analyzed. In this case, in order to avoid contamination, the first slag jet (easily distinguishable from tin and FeSnSi due to color difference) was neglected and a sample of the intermediate 
portion of the final slag stream was obtained. FeSnSi was sampled according to ISO 3713 [11]. With respect to crude tin, a liquid sample was taken with the aid of a steel recipient immediately after its tapping in order to avoid possible decantation effect of impurities.

The chemical analysis of the concentrate is shown in Table 1. The column named "Others" represents other elements, as well as traces of $\mathrm{ThO}_{2}$ and $\mathrm{U}_{3} \mathrm{O}_{5}$. For better control, the concentrate of each test was sampled separately. Almost all chemical analysis present in this work were performed by X-ray fluorescence and exceptions are the tin content of concentrates, final slags, FeSnSi and filter dust, which were analyzed by titrimetric method for higher precision, and crude tin, which was analyzed by atomic absorption spectrometry.

Table 1. Composition of the tin slag concentrate

\begin{tabular}{ccccccccccccc}
\hline & $\mathrm{SnO}_{2}$ & $\mathrm{SiO}_{2}$ & $\mathrm{FeO}$ & $\mathrm{CaO}$ & $\mathrm{ZrO}_{2}$ & $\mathrm{Nb}_{2} \mathrm{O}_{5}$ & $\mathrm{Al}_{2} \mathrm{O}_{3}$ & $\mathrm{TiO}_{2}$ & $\mathrm{MgO}$ & Others & Basicity \\
\hline $\begin{array}{c}\text { Mean value } \\
(\%)\end{array}$ & 25.3 & 18.9 & 11.3 & 10.8 & 13.3 & 6.9 & 2.8 & 2.1 & 1.9 & 6.8 & 0.57 \\
\hline$\sigma(\%)$ & 2.2 & 0.7 & 2.0 & 0.6 & 1.7 & 0.5 & 0.1 & 0.1 & 0.1 & 0.5 & 0.03 \\
\hline
\end{tabular}

Charcoal, limestone, quartz and metallic Si were used in the charge. The analyses are shown in Table 2. The addition of metallic $\mathrm{Si}$ is necessary for the formation of a FeSnSi alloy with low solubility of tin, thus allowing greater generation of crude tin and consequently higher yield [5].

Table 2. Composition of fluxes and additions

\begin{tabular}{ccccc}
\hline & $\mathbf{C}$ & $\mathbf{C a O}$ & $\mathrm{SiO}_{2}$ & $\mathrm{Si}$ \\
\hline Limestone (\%) & - & 53.4 & 1.1 & - \\
\hline Charcoal (\%) & 76.0 & - & - & - \\
\hline Quartz (\%) & - & - & 98.2 & - \\
\hline Metallic Si (\%) & - & - & - & 99.03 \\
\hline
\end{tabular}

The charge was calculated, considering the average slag analysis, for a theoretical basicity of 0.78 . A simple mass balance involving masses of $\mathrm{CaO}$ and $\mathrm{SiO}_{2}$ from the concentrate added to the masses of $\mathrm{CaO}$ and $\mathrm{SiO}_{2}$ from the additions was considered in this initial calculation, which is demonstrated for $\mathrm{SiO}_{2}$ in Formula 1. The term Mass $\left(\mathrm{SiO}_{2}\right)_{\text {Additions }}$ is determined by the $\mathrm{SiO}_{2}$ contents and quantities of the additions used.

$$
\text { Mass }\left(\mathrm{SiO}_{2}\right)_{\text {Slag }}=\% \mathrm{SiO}_{2} \text { Concentrate } * \text { Mass (Concentrate) }+ \text { Mass }\left(\mathrm{SiO}_{2}\right)_{\text {Additions }}
$$

Although the basicity value of 0.78 does not reflect the lowest melting temperature of a slag considering the $\mathrm{CaO}-\mathrm{FeO}_{x}-\mathrm{SiO}_{2}$ phase system, a batch targeting lower temperatures at a much lower basicity (0.59) led to operational problems. The presence of viscous slag and unmelted material was noticed and hindered tapping. It was necessary to add limestone (up to $12 \%$ of the mass of concentrate) so that tapping could be carried out. Therefore, a charge empirically determined was chosen and it allowed the conduction of the present study. It is shown in Table 3, which describes the percentage of each addition in relation to the mass of concentrate. 
Table 3. Charge used in the experiments

\begin{tabular}{cccc} 
Charcoal (\%) & Metallic Si (\%) & Limestone (\%) & Quartz (\%) \\
\hline 6 & 1.7 & 12 & 2.7 \\
\hline
\end{tabular}

After the results, a complete mass balance was conducted considering the analyses and masses of the concentrate, fluxes, additions and outputs. For example, the determination of the mass of $\mathrm{SiO}_{2}$ in the slag could be calculated by Formula 2.

$$
\begin{aligned}
\text { Mass }\left(\mathrm{SiO}_{2}\right)_{\text {Slag }} & =\% \mathrm{SiO}_{2 \text { Concentrate }}{ }^{*} \text { Mass }(\text { Concentrate })+\text { Mass }\left(\mathrm{SiO}_{2}\right)_{\text {Additions }} \\
& - \text { Mass }\left(\mathrm{SiO}_{2}\right)_{\text {Reduced }}
\end{aligned}
$$

The term Mass $\left(\mathrm{SiO}_{2}\right)$ Reduced represents the quantity of $\mathrm{SiO}_{2}$ which was reduced in the process. It can be understood in detail through Formula 3, in which MM represents the molar mass. The mass of $\mathrm{Si}$ resulting from reduction is expressed as the difference between the quantity found in the FeSnSi alloy and the amount of Si added through the inputs. If the value of Mass $\left(\mathrm{SiO}_{2}\right)$ Reduced is negative, oxidation of $\mathrm{Si}$ occurred. This is a phenomenon of importance since it would be able to influence the basicity and therefore the melting temperature of the slag.

$$
\text { Mass }\left(\mathrm{SiO}_{2}\right)_{\text {Reduced }}=\left(\operatorname{Mass}(\mathrm{Si})_{\mathrm{FeSnSi}}-\operatorname{Mass}(\mathrm{Si})_{\text {Addition }}\right) \frac{\mathrm{MM}\left(\mathrm{SiO}_{2}\right)}{\mathrm{MM}(\mathrm{Si})}
$$

Another important calculation is the mass of tin in the slag. Being tin a valuable metal, all losses must be taken into account. This calculation is shown in Formula 4.

$$
\begin{aligned}
& \text { Mass }\left(\mathrm{SnO}_{2}\right)_{\text {Slag }}=\text { Mass }\left(\mathrm{SnO}_{2}\right)_{\text {Concentrate }}-\left(\text { Mass }(\mathrm{Sn})_{\mathrm{FeSnSi}}\right. \\
& \left.+ \text { Mass }(\mathrm{Sn})_{\text {Crude tin }}\right) * \frac{\mathrm{MM}\left(\mathrm{SnO}_{2}\right)}{\mathrm{MM}(\mathrm{Sn})}-\text { Mass }\left(\mathrm{SnO}_{2}\right)_{\text {Filter dust }}
\end{aligned}
$$

With the calculation being performed for all elements, the mass of each oxide was determined. A theoretical mass of slag was calculated and therefore also its composition. A comparison was conducted between these results and the chemical analyses. Formula 5 exemplifies this calculation for $\mathrm{CaO}$.

$$
\text { Difference }(\% \mathrm{CaO})=\text { Measured }(\% \mathrm{CaO})-\text { Calculated }(\% \mathrm{CaO})
$$

In order to predict the slag composition, it is necessary to measure the masses of filter dust, FeSnSi and crude tin, as well as their compositions. If the model is used for the prediction of a future operation, statistical data need to be collected, for example the average generation and composition of FeSnSi alloy, the average loss of tin for the exhausting system and the average yield of tin considering crude tin. Based on this information, not only an elementary mass balance, but also a statistical 
analysis of the operation including measurement of the average compositions of the outputs was performed.

\section{RESULTS AND DISCUSSION}

The mean composition and standard deviation of the final slags are shown in Table 4. The column named "Others" represents other elements as well as traces of $\mathrm{ThO}_{2}$ and $\mathrm{U}_{3} \mathrm{O}_{5}$.

Table 4. Composition of final slags

\begin{tabular}{cccccccccccc}
\hline & $\mathrm{SnO}_{2}$ & $\mathrm{SiO}_{2}$ & $\mathrm{FeO}$ & $\mathrm{CaO}$ & $\mathrm{ZrO}_{2}$ & $\mathrm{Nb}_{2} \mathrm{O}_{5}$ & $\mathrm{Al}_{2} \mathrm{O}_{3}$ & $\mathrm{TiO}_{2}$ & $\mathrm{MgO}$ & Others & Basicity \\
\hline $\begin{array}{c}\text { Mean value } \\
(\%)\end{array}$ & 7.1 & 30.5 & 6.4 & 22.1 & 14.6 & 5.2 & 3.4 & 2.0 & 1.8 & 7.0 & 0.73 \\
\hline$\sigma(\%)$ & 0.8 & 3.0 & 0.1 & 1.7 & 1.4 & 0.9 & 0.3 & 0.2 & 0.3 & 0.7 & 0.11 \\
\hline
\end{tabular}

As can be noted in Table 4, the mean basicity of the final slag, initially predicted at 0.78 through mass balance using Formula 1, was not confirmed. In contrast, a lower mean value, equal to 0.73 , was measured.

After a more complete mass balance (using Formulas 2,3 and 4) was performed, the calculations were able to predict the composition of the slag according to Table 5, which explains the composition difference between measured and calculated values for the final slag (Formula 5).

Table 5. Difference between measured and calculated values for each oxide and for the basicity

\begin{tabular}{cccccccccccc}
\hline & $\mathrm{SnO}_{2} \mathrm{SiO}_{2}$ & $\mathbf{F e O}$ & $\mathrm{CaO}$ & $\mathrm{ZrO}_{2}$ & $\mathrm{Nb}_{2} \mathrm{O}_{5}$ & $\mathrm{Al}_{2} \mathrm{O}_{3}$ & $\mathrm{TiO}_{2}$ & $\mathbf{M g O}$ & Others & Basicity \\
\hline $\begin{array}{c}\text { Mean value } \\
(\%)\end{array}$ & 0.8 & 0.7 & 5.0 & 0.2 & -2.3 & -1.3 & -0.2 & -0.5 & -0.6 & -1.1 & -0.01 \\
\hline$\sigma(\%)$ & 2.2 & 3.6 & 2.9 & 2.1 & 1.7 & 1.8 & 0.3 & 0.2 & 0.3 & 1.0 & 0.12 \\
\hline
\end{tabular}

As can be seen by the difference for the basicity, the new calculation generated a value much closer to the measured value. This is because it takes into account the oxidation of $\mathrm{Si}$. Considering the basicity as a relation between $\mathrm{CaO}$ and $\mathrm{SiO}_{2}$ and that the only metallic additive used was metallic Si, it can be concluded that there was a partial oxidation of this addition, resulting in reduction of basicity. It was verified that in average only $48.3 \%$ of the added Si could actually be found in the alloy. In other words, $51.7 \%$ was oxidized and therefore it is responsible for the displacement of the slags basicity values.

The mean composition of FeSnSi and Crude tin is shown in Table 6.

Table 6. Composition of FeSnSi and Crude tin

\begin{tabular}{cccccccc}
\hline & Fe & Sn & Si & Nb & Pb & Zn & Others \\
\hline Mean value FeSnSi $(\%)$ & 69.3 & 10.1 & 5.8 & 9.3 & - & - & 5.5 \\
\hline$\sigma$ FeSnSi $(\%)$ & 11.0 & 2.8 & 1.8 & 5.7 & - & - & 3.8 \\
\hline Mean value Crude tin (\%) & 2.3 & 93.9 & - & - & 3.7 & 0.1 & 0.1 \\
\hline$\sigma$ Crude tin (\%) & 0.31 & 0.7 & - & - & 0.8 & 0.1 & 0.1 \\
\hline
\end{tabular}

The filter dust was analyzed and the tin content amounted 18.1\%. Figure 2 shows a mass balance of the process, considering the recovery of tin. 


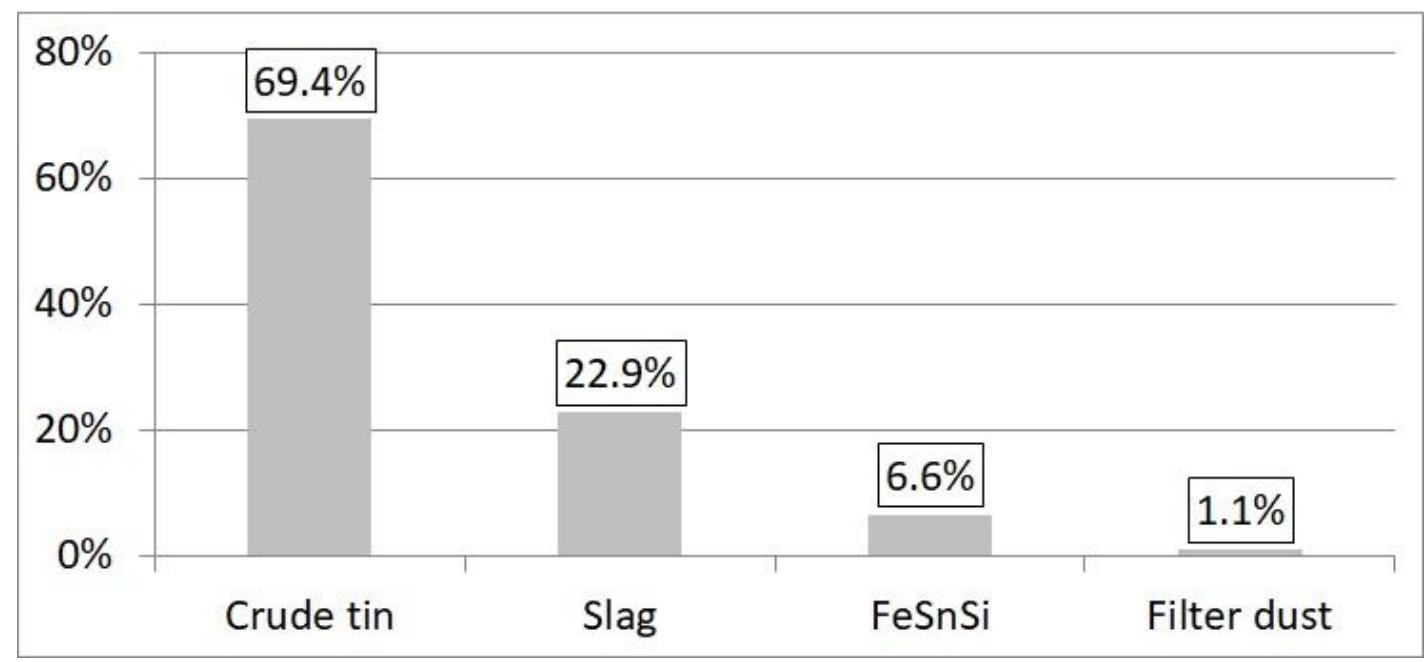

Figure 2. Distribution of tin in the outputs considering all tests performed.

Through several measurements of the metal/slag stream during tapping, it was possible to determine a range between 1833 and $1873 \mathrm{~K}$ for the tapping temperature. Strong variation of temperature during the same tapping was noticed.

Considering this temperature range, studying the slag in the $\mathrm{CaO}-\mathrm{FeO}-\mathrm{SiO}_{2}$ phase system aided to understand the effect of displacement of basicity due to oxidation of $\mathrm{Si}$. However, the most interesting result was found in the analysis of the slag under the scope of the $\mathrm{ZrO}_{2}-\mathrm{CaO}-\mathrm{SiO}_{2}$ phase system. These studies as well as results from another sampling method will be described, which proved to be an important factor for understanding the slag composition.

\section{1 $\mathrm{CaO}-\mathrm{FeO} x-\mathrm{SiO}_{2}$ phase system}

The concentrate and average final slag composition from this work are shown in Figure 3 for the $\mathrm{CaO}-\mathrm{FeO}_{x}-\mathrm{SiO}_{2}$ phase system. It can be noted that the average final slag composition, considering these elements, is close to the line representing $\mathrm{CaO} . \mathrm{SiO}_{2}$, which has a liquidus temperature of $1817 \mathrm{~K}\left(1544^{\circ} \mathrm{C}\right)$. Although the effect of displacement of the basicity due to $\mathrm{Si}$ oxidation could possibly lead to higher temperatures within this system, there is still a long range in which the slag would be fluid, considering measured tapping temperatures. 


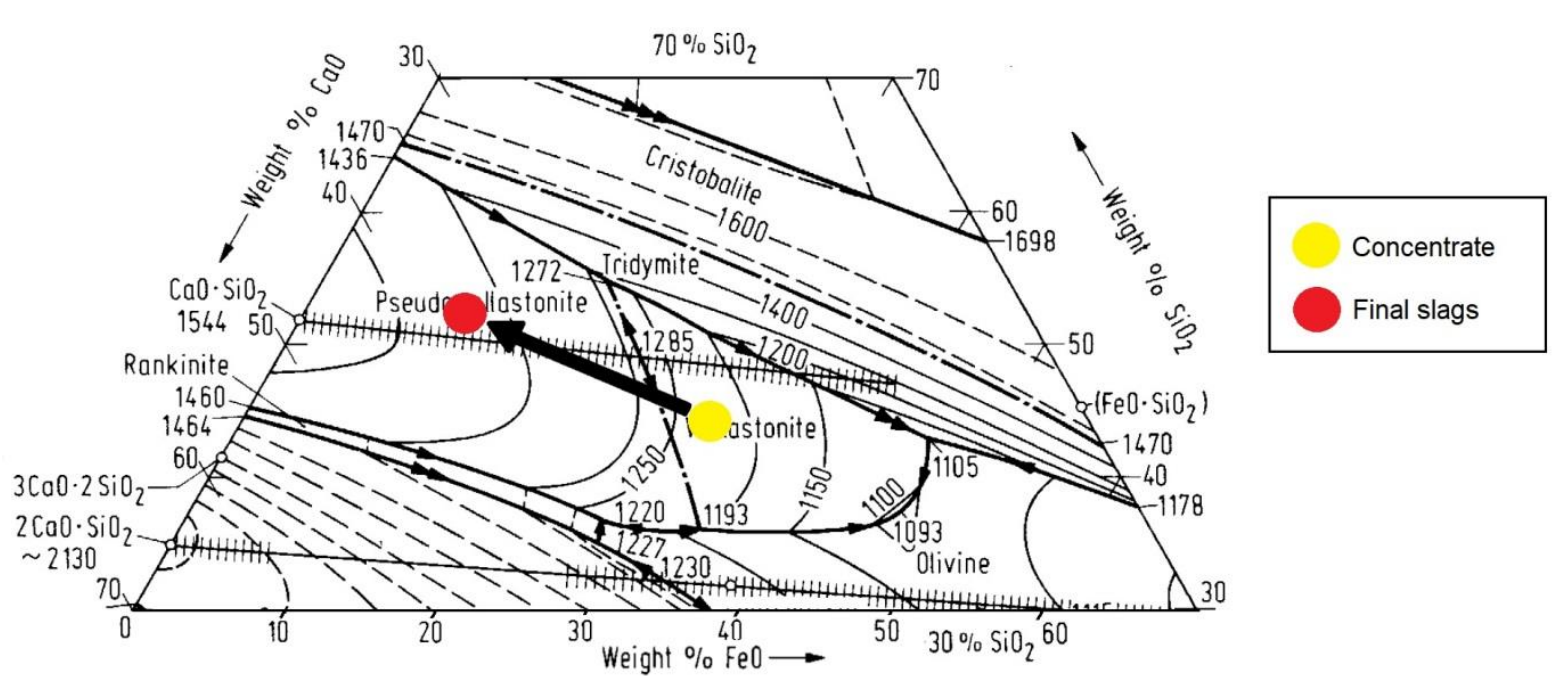

Figure 3. Concentrate and final slag of the present work considering the $\mathrm{CaO}-\mathrm{FeO}_{x}-\mathrm{SiO}_{2}$ phase system. Adapted from Wright [5] and Verein Deutscher Eisenhüttenleute [8].

It is also noteworthy that the tin content in the final slag is very high when compared with those presented by Wright [5] (which lies between $0.1 \%$ and $1 \% \mathrm{SnO}_{2}$ ). In order to understand the reason for the high tin content found in the final slag, a qualitative test was performed on a magnetic separator, revealing the presence of a metallic fraction in the slag. The analysis of this fraction is found in Table 7 and is similar to the FeSnSi shown in Table 6.

Table 7. Composition of metallic fraction in the slag

\begin{tabular}{lcccc}
\hline & Fe & Sn & Si & $\mathbf{~ N b}$ \\
\hline Composition of the metallic fraction (\%) & 79.5 & 8 & 5.5 & 4.1 \\
\hline
\end{tabular}

It can be concluded that part of the FeSnSi was not completely separated from the slag, either due to incomplete settling, or even because of the separation difficulty at the FeSnSi/slag interface. This fact led to a new specific test, aiming to understand the influence of this metal fraction on the composition of the slag. In this test, which followed the same assumptions as the others, the slag was sampled during tapping for three consecutive runs. Further, the final slag was ground and sampled for comparison. The results are shown in Table 8.

Table 8. Comparison between ground final slag and samples taken during tapping

$\mathrm{SnO}_{2} \mathrm{SiO}_{2} \mathrm{FeO} \mathrm{CaO} \mathrm{ZrO}_{2} \quad \mathrm{Nb}_{2} \mathrm{O}_{5} \quad \mathrm{Al}_{2} \mathrm{O}_{3} \quad \mathrm{TiO}_{2} \mathrm{MgO}$ Others $\mathrm{CaO} / \mathrm{SiO}_{2}$

\begin{tabular}{cccccccccccc}
\hline 1st sample (\%) & 2.0 & 30.1 & 1.7 & 25.8 & 20.9 & 3.5 & 3.2 & 1.9 & 1.9 & 9.0 & 0.86 \\
\hline 2nd sample (\%) & 1.4 & 31.9 & 1.5 & 25.4 & 20.8 & 3.4 & 3.3 & 1.9 & 1.8 & 8.6 & 0.79 \\
\hline 3rd sample (\%) & 0.8 & 31.4 & 1.4 & 25.7 & 21.3 & 3.4 & 3.3 & 1.9 & 1.8 & 9.0 & 0.82 \\
\hline Ground slag (\%) & 6.1 & 28.7 & 6.0 & 22.4 & 15.7 & 5.5 & 3.1 & 2.0 & 1.6 & 8.9 & 0.78 \\
\hline
\end{tabular}

It is clear that the presence of FeSnSi causes changes in the slag composition. The metallic fraction implies high levels of tin in the final slag and an optimization of the process, in order to reduce slags recirculation, is possible through the recovery of this fraction in the process itself. A strong increase in the $\mathrm{ZrO}_{2}$ contents can also be noted, which justifies the analysis of the slag under the scope of the $\mathrm{ZrO}_{2}-\mathrm{CaO}-\mathrm{SiO}_{2}$ phase system and reinforces the difficulties to analyze the slag using the $\mathrm{CaO}-\mathrm{FeO}_{x}-$ $\mathrm{SiO}_{2}$ phase system for this concentrate. 
Regarding the basicity, there was a variation among the three samples taken during tapping. Considering that the operational test continued after samples were taken, this variation is attributed to fluctuations in slag composition throughout the process.

\section{2 $\mathrm{ZrO}_{2}-\mathrm{CaO}-\mathrm{SiO}_{2}$ phase system}

According to the viscosity model from Urbain et al described by Verein Deutscher Eisenhüttenleute [8], the presence of high contents of $\mathrm{ZrO}_{2}$ should lower the viscosity of final slags. This can be seen in Figure 4, which shows a comparison for the theoretical viscosity of the mean composition of slags sampled during tapping (Table 8) with and without considering $\mathrm{ZrO}_{2}$ contents.

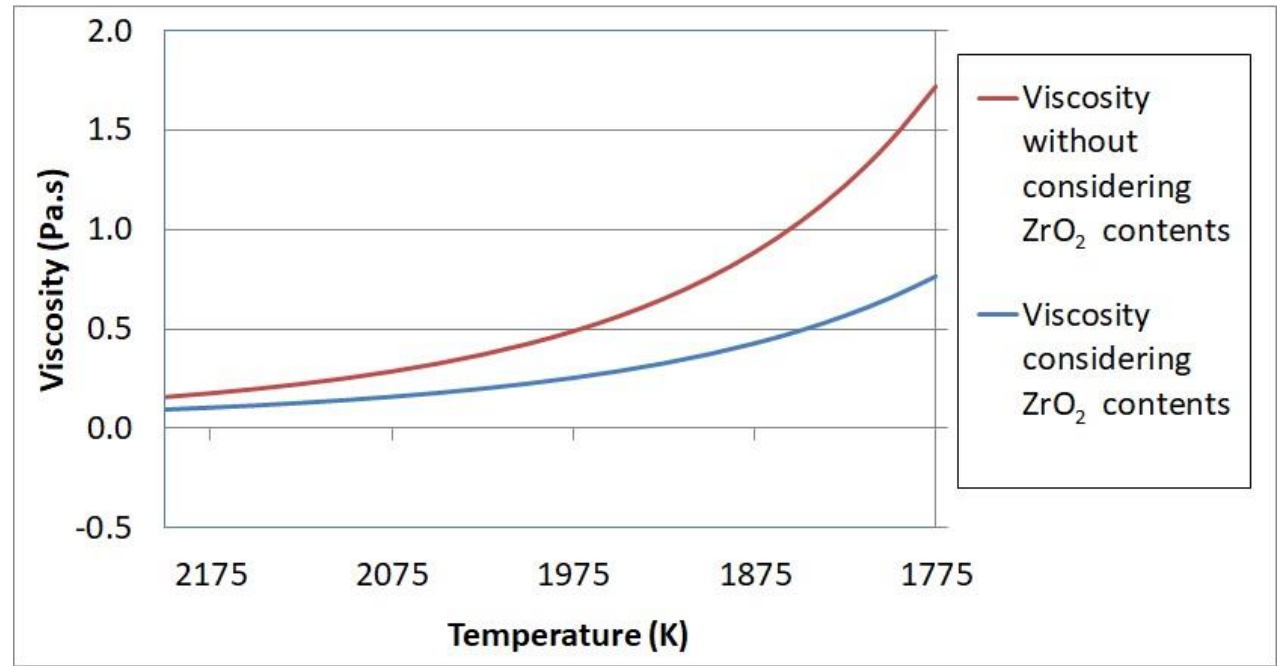

Figure 4. Viscosity of final slags according to the model proposed by Urbain et al as described by Verein Deutscher Eisenhüttenleute [8].

It can be understood that the presence of $\mathrm{ZrO}_{2}$ should be beneficial for the process assuming the slag is completely molten. However, using the data provided by Kwon [9] for the $\mathrm{ZrO}_{2}-\mathrm{CaO}-\mathrm{SiO}_{2}$ system at $1873 \mathrm{~K}$, which is close to tapping temperatures of the present work, there is strong indication that due to the presence of high contents of $\mathrm{ZrO}_{2}$, the final slags studied are not completely fluid. This would explain why high levels of tin were found in final slags. Tin would be at least partly in the FeSnSi alloy not decanted due to a high apparent viscosity (presence of solid fraction) of the slag.

As can be seen in Figure 5, the liquid phase in the $\mathrm{ZrO}_{2}-\mathrm{CaO}-\mathrm{SiO}_{2}$ system is obtained approximately for $\mathrm{ZrO}_{2}$ contents inferior to $17 \%$ and between the basicity values of 0.5 and 1.5. Considering that final slags of the present work are well represented by the $\mathrm{ZrO}_{2}-\mathrm{CaO}-\mathrm{SiO}_{2}$ system, as shown in Table 8, it can be verified that the basicity is not a critical factor at this temperature. The control of $\mathrm{ZrO}_{2}$ contents is much more important, so that the slag can be fluid at working temperatures. 


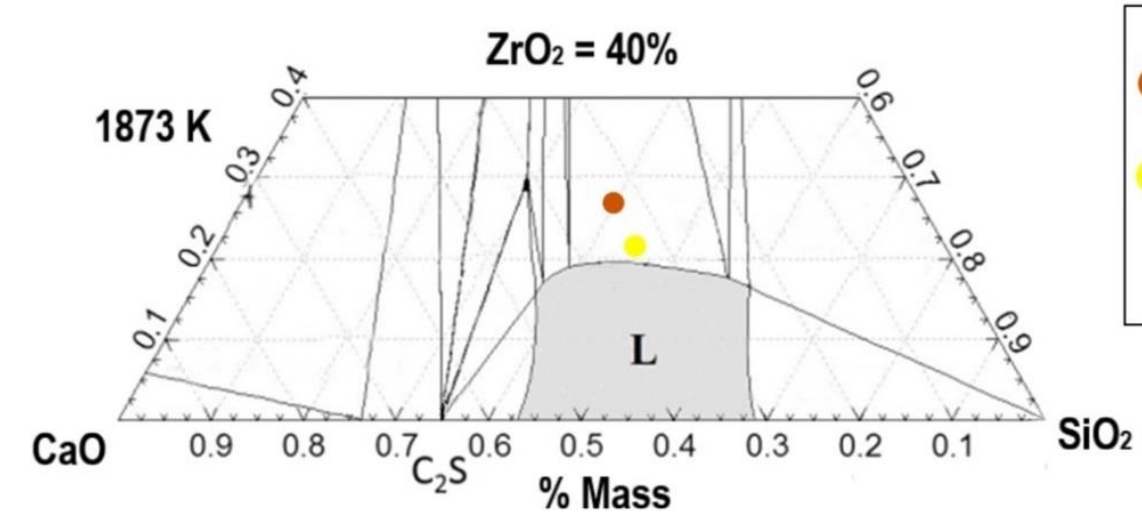

Samples taken

during tapping

Samples taken from ground slag

$\mathrm{C}_{2} \mathrm{~S}-\mathrm{Ca}_{2} \mathrm{SiO}_{4}$

Figure 5. Isothermal $\mathrm{ZrO}_{2}-\mathrm{CaO}-\mathrm{SiO}_{2}$ phase diagram at $1873 \mathrm{~K}$. Adapted from Kwon [9].

The addition of fluxes is interesting for decreasing the $\mathrm{ZrO}_{2}$ content to levels below $17 \%$ and obtaining therefore a slag with high fluidity. According to Wright [5], this property controls the rate of metal/slag separation. The present work suggests reaching this result by dilution of $\mathrm{ZrO}_{2}$ through addition of fluxes. There would be then greater recovery of tin and as consequence decrease in slags recirculation. The proposed model can be used to predict $\mathrm{ZrO}_{2}$ contents, as shown in Table 5, and therefore to optimize the addition of fluxes.

\section{CONCLUSION}

A theoretical model was developed in order to predict the composition of final tin slags, originated from processing of concentrates. The prediction of basicity requires taking into account possible reactions of the inputs with the bath (reduction / oxidation of elements).

It has been found that the sampling method is important for understanding the composition of final slags and the process itself. In contrast to sampling of ground slag, sampling during tapping revealed higher $\mathrm{ZrO}_{2}$ and lower $\mathrm{FeO}$ and $\mathrm{SnO}_{2}$ contents in the final slag. Therefore, slags studied in this work are better described by the $\mathrm{CaO}-\mathrm{SiO}_{2}-\mathrm{ZrO}_{2}$ phase system.

A theoretical approach on the slags viscosity revealed that higher $\mathrm{ZrO}_{2}$ contents should lower the viscosity of the slag. However, as seen in Figure 5, final slags are not completely fluid, indicating a high apparent viscosity. The presence of a metallic phase in the final slag was verified and it can be attributed to this factor. This metallic phase is rich in tin and an optimization of the process involves a greater recovery of this metal.

Thus, final slags should be modeled in order to obtain lower melting temperatures, allowing better slag/metal separation. In this context, dilution of $\mathrm{ZrO}_{2}$ contents should be performed through addition of fluxes. It is then possible to obtain a liquid final slag, to reduce the presence of metallic phase in this slag and therefore the recirculation of slags containing thorium and uranium oxides.

Although with the restrictions imposed by the presence of the metallic phase in the slag, the present model can be used to predict the $\mathrm{ZrO}_{2}$ contents accurately. Further studies on final slags sampling during tapping can elucidate the differences found for 
the basicity and lead to the optimization of the developed model. Also, considering the high melting temperatures of studied slags, a research on the addition of different fluxes can also contribute to a decrease in slags recirculation.

\section{REFERENCES}

1. Basic Safety Standard. Council Directive 2013/59/EURATOM of 5 December 2013 laying down basic safety standards for protection against the dangers arising from exposure to ionising radiation, and repealing Directives 89/618/Euratom, 90/641/Euratom, 96/29/Euratom, 97/43/Euratom and 2003/122/Euratom. Off J Eur Union. 13th ed. 2014 Jan 17;1-73.

2. CNEN. Requisitos de segurança e proteção radiológica para instalações mínero-industriais [Internet]. 2016 [cited 2017 Mar 2]. Available from: http://appasp.cnen.gov.br/seguranca/normas/pdf/Nrm401.pdf

3. Haridasan PP, Harikumar M, Ravi PM, Tripathi RM. Radiological protection against exposure to naturally occurring radioactive material. Radiat Prot Env. 2015;38(3):59-67.

4. World Nuclear Association. Naturally occurring radioactive materials NORM World Nuclear Association [Internet]. 2016 [cited 2017 Mar 2]. Available from: http://www.world-nuclear.org/information-library/safety-and-security/radiationand-health/naturally-occurring-radioactive-materials-norm.aspx

5. Wright PA. Extractive metallurgy of tin. 2nd completely rev. ed. Amsterdam: Elsevier Scientific Pub. Co; 1982. 93-151 p. (Process metallurgy).

6. Pretorius EB, Marr R. The effect of slag modeling to improve steelmaking processes. In: 53rd ISS Electric Furnace Conference Proceedings [Internet]. USA: Iron and Steel association of AIME; 1995 [cited 2017 Mar 4]. p. 407-15. Available

from: http://etech.Iwbref.com/Downloads/Theory/The\%20effect\%20of\%20slag\%20mo deling\%20to\%20improve\%20steelmaking\%20processes.pdf

7. Pretorius EB. Fundamentals of EAF and ladle slags and ladle refining principles [Internet]. Magnesita e-Tech. 2015 [cited 2017 Mar 4]. Available from: http://etech.Iwbref.com/Downloads/Theory/Fundamentals\%20of\%20EAF\%20an d\%20ladle\%20slags\%20and\%20ladle\%20refining\%20principles.pdf

8. Verein Deutscher Eisenhüttenleute. Slag atlas. 2nd ed., Repr. without change. Düsseldorf: Verl. Stahleisen; 1995. 126,349-354.

9. Kwon SY. Thermodynamic optimization of ZrO2-containing systems in the $\mathrm{CaO}-$ $\mathrm{MgO}-\mathrm{SiO} 2-\mathrm{Al} 2 \mathrm{O} 3-\mathrm{ZrO} 2$ system [master's thesis]. [Montreal, Canada]: McGill University; 2015.

10. ASTM Internacional. Standard practice for sampling aggregates [Internet]. 2014 [cited 2017 Jun 5]. Available from: http://www.astm.org/cgibin/resolver.cgi?D75D75M-14

11. International Organization for Standardization. ISO 3713. 1987 Dec. Available from: https://www.iso.org/standard/9190.html 